\title{
Why Don't People Think Evolution Is True? Implications for Teaching, In and Out of the Classroom
}

\author{
Warren D. Allmon
}

Published online: 14 December 2011

(C) Springer Science+Business Media, LLC 2011

\begin{abstract}
The causes of non-acceptance of evolution are groupable into five categories: inadequate understanding of the empirical evidence and the content of modern evolutionary theory, inadequate understanding of the nature of science, religion, various psychological factors, and political and social factors. This multiplicity of causes is not sufficiently appreciated by many scientists, educators, and journalists, and the widespread rejection of evolution is a much more complicated problem than many of these frontline practitioners think it is. Solutions to the widespread non-acceptance of evolution must therefore involve not just further resolution of the "religion vs. science" controversy. They must also involve better communication of empirical evidence for evolution, more effective explication of the nature of science, and explicitly addressing the numerous significant psychological obstacles that evolution presents to many (perhaps most) people. There is no clear roadmap to how to do all of this, but some practical recommendations include (1) more research on why and when different people accept or do not accept evolution when they are exposed to it, especially the role of "scientific" vs. "affective" causes for non-acceptance, and also on apparently deeply rooted psychological obstacles to acceptance. (2) A more explicit approach to explication and understanding of the causes for non-acceptance of evolution should support the often-stated goal of understanding "where students are" prior to implementing the kind of approaches frequently advocated for teaching evolution. (3) Integration of multiple educational perspectives and
\end{abstract}

\footnotetext{
W. D. Allmon $(\bowtie)$

Paleontological Research Institution, and Department of Earth and Atmospheric Sciences, Cornell University,

1259 Trumansburg Road,

Ithaca, NY 14850, USA

e-mail: wda1@cornell.edu
}

academic disciplines to support application of pedagogical strategies in actual educational settings. (4) Increased development and application of approaches to evolution education in settings beyond the $\mathrm{K}-16$ classroom, such as museums, nature centers, zoos, parks, and aquaria.

Keywords Evolution C Creationism · Belief - Acceptance . Religion $\cdot$ Psychology $\cdot$ Politics

It is almost as if the human brain were specifically designed to misunderstand Darwinism, and to find it hard to believe. (Dawkins 1996)

Why people do not believe in evolution has no simple answer. (Williams 2009)

I know of no safe depository of the ultimate powers of the society but the people themselves; and if we think them not enlightened enough to exercise their control with a wholesome direction, the remedy is not to take it from them, but to inform their discretion by education. (Thomas Jefferson to William C. Jarvis, Sept. 28, 1820)

\section{Introduction}

About half of American adults do not accept organic evolution as an accurate factual statement about nature, a number that, according to polls, has remained approximately constant over the past several decades (Bishop 2007; Plutzer and Berkman 2008). The U.S. ranks near the bottom of industrialized countries in which acceptance of evolution has been polled (Mazur 2005; Miller et al. 2006), 
although there are signs that non-acceptance of evolution may be rising in other countries (e.g., Cornish-Bowden and Cárdenas 2007; Branch 2008; Williams 2009; Brown 2010). Surveys of American college students similarly indicate low levels of both acceptance and knowledge of evolution (Nehm and Reilly 2007; Lovely and Kondrick 2008; Cunningham and Wescott 2009; Jakobi 2010). Surveys of American public school teachers also find wide variation in knowledge, belief, and amount of class time devoted to evolution (Rutledge and Warden 2000; Rutledge and Mitchell 2002; Trani 2004; Bowman 2008; Berkman et al. 2008; Moore 2008; Moore and Cotner 2009; Berkman and Plutzer 2010, 2011; Deniz and Donnelly 2011). In other words, there is a "great disconnect" between the views of scientists and nonscientists on evolution (Wiles 2010). Evolution "remains a minority view in the general understanding" (Nickels et al. 1996), and most Americans (and many people elsewhere) "view the biological world from a kind of pre-Darwinian perspective" (Rudolph and Stewart 1998).

In response, much attention has been devoted in the past 20 years, by both scientists and educators, to the field that has come to be known as "evolution education" (Smith et al. 1995; National Academy of Sciences 1998; Alters and Alters 2001; Alters and Nelson 2002; Alters 2005; Wilson 2005; Diamond 2006; Meadows 2009; O’Brien et al. 2009; Nehm and Schonfeld 2007; Ellis 2010; Smith 2010a, b; Oliveira et al. 2011). As a result, it is no longer true that students' understanding of evolution is under-researched (Cummins et al. 1994), and we now know a great deal more than we used to about what students think about evolution and what pedagogical approaches work and why.

Less attention, however, has been given to the causes for these high levels of non-acceptance (aka "disbelief," "rejection," "denial") in the first place. Although this question has recently been the subject of increased discussion and research (e.g., Evans 2008; Hokayem and BouJaoude 2008; Richards 2008; Sinatra et al. 2008; Thagard and Findlay 2009; Williams 2009; Mead and Scott 2010a, b; Nadelson and Southerland 2010; Smith 2010a, b; Tracy et al. 2011; Shtulman 2011; Shtulman et al. 2008; Kampourakis and McComas 2010; Wiles et al. 2011), and there is growing agreement on the general conclusion that the causes of nonacceptance of evolution are numerous, diverse, and complex; most of the scholarly literature on this topic treats causes one or two at a time; and many if not most discussions for students or general readers are relatively brief and/or oversimplified (e.g., Freeman and Herron 2007; Coyne 2009a; Futuyma 2009; Meadows 2009; Shermer 2006), or also focus on only one or two potential causes. Yet this is not the way most students or members of the general public come to evolution; they arrive with all of these numerous, diverse, and complex factors mixed up in their minds in ways that even they may not understand. Religion, for example, is not the only or even the main source of resistance to evolution for many people; it interacts in complex ways with numerous other factors which, if unacknowledged, can scuttle attempts to increase acceptance of evolution. Furthermore, most of the attention given this topic in the literature has focused on classroom settings, and not on venues outside the classroom (which are more numerous and, arguably, more important for life-long learning). My own experience in evolution education over the past three decades - in high school and college undergraduate classes, as well as in museums and other "informal" venues - strongly suggests that, despite all of the research conducted and published during these years, the practitioners who develop and present content on the front lines-professors, teachers, informal educators, exhibit designers, film producers, and others - still lack an accessible but authoritative overview of all of the potential major causes for resistance to or non-acceptance of evolution. Without such an overview, these practitioners can only proceed with some combination of (1) assuming that we already know the one or two causes and how to deal with them and applying a onesize-fits-all pedagogy that assumes that all resistance to evolution is due to these causes, or (2) delving into the scholarly literature and assembling their own list of possible causes and tools for assessing which ones are most important for their particular audiences.

Justification for such an overview also comes from another source. As has been argued by several authors (e.g., Lipps 2006; Cornish-Bowden and Cárdenas 2007; Prothero 2007), evolution education is not just about teaching in the traditional sense. Most opponents of evolution do not operate within traditional structured educational settings, practices, or budgets. On the contrary, they tend to work through non-educational institutions (such as churches) and the popular media, and they are frequently better funded than advocates for evolution. In other words, evolution education is also about marketing. Just as in commercial marketing, in which "understanding what motivates the audience is critical to creating effective advertising" (Wells et al. 2006), understanding the full spectrum of causes for why so many people do not think evolution is true is critical for increasing their acceptance. Just as advertising may fail if it is not targeted at what consumers really think or feel, evolution education may fail if educators assume incorrectly that they know why their particular target learners do not accept what they are saying. Commercial advertisers know that consumers decide on purchases for a wide variety of reasons, from emotional to rational: because something catches their eye in the checkout, or because they have done careful research and follow an "information-driven process," or something in between (Wells et al. 2006). Similarly, people reject evolution not only because of their religious beliefs but also because of a combination of other factors, including inadequate or erroneous factual knowledge; multiple, deep psychological 
obstacles; and sociopolitical factors. It may frequently be difficult to determine what this combination is, but only with some awareness of the full spectrum of potential causes of this resistance can educators select pedagogical approaches that might be appropriate for the needs of their particular audience, both in and outside the classroom.

Several classifications of the causes for non-acceptance of evolution have been proposed (Alters and Alters 2001; Alters 2005; Smith 2010a, b; Wiles et al. 2011). I follow these fairly closely here but at the highest level divide causes into what may be called "proximate" or "primary" causes for individual non-acceptance of evolution (Table 1) as opposed to the numerous potential "ultimate" or "secondary" explanations for why the primary causes exist and seem to be resistant to change (Table 2) (the latter constitute their own enormous topic that is beyond the scope of this paper). For example, college students may not accept evolution mainly because they harbor numerous factual misconceptions about it; this is a "proximate/ primary" reason. Those students may, however, have so many misconceptions for the "ultimate/secondary" reason that the teaching of evolution is ineffective.

Recent reviews of potential causes for non-acceptance of evolution (e.g., Smith 2010a, b; Wiles et al. 2011) also discuss pedagogical strategies for addressing at least some of these causes. Most of these discussions, however, apply only or largely to the formal or classroom setting and give less attention to how the same causes affect views outside the classroom. Yet it is here that people spend most of their lives (Falk and Dierking 2010). In this paper, therefore, I try to focus on the proximal/primary causes for nonacceptance not only in the classroom but also in informal educational settings, such as museums, which are major potential resources for evolution education (Evans et al. 2010; Allmon et al. 2012).

The overview presented here is primarily a statement of the problem rather than a set of proposed solutions. This

Table 1 Summary classification of "proximate/primary" causes of non-acceptance of evolution

Scientific causes
Insufficient knowledge of empirical evidence
Insufficient knowledge/misunderstanding of evolutionary theory
Insufficient knowledge/misunderstanding of the nature of science
Affective causes
Religious obstacles
Psychological obstacles
Counter-empirical
Biases in how we see the world
Logical thinking
Political/social obstacles

Table 2 Some major "ultimate/secondary" causes for widespread non-acceptance of evolution in the United States

General anti-intellectualism (see, e.g., Hofstadter 1963; Pierce 2009)

Low scientific literacy (Hazen and Trefil 2009) and/or distrust of science (e.g., Sagan 1996; Mooney and Kirschenbaum 2009; Berkman and Plutzer 2009, 2010)

Poor teaching (of science generally and evolution in particular) (e.g., Alters and Nelson 2002)

Strength, diversity, and decentralization of American religious belief (Lachman 1993; Numbers 2006)

Decentralization of American public education (Antolin and Herbers 2001; Berkman and Plutzer 2010)

paper focuses on why individuals think evolution is not true, not on what exactly to do about that. Since, however, the reason for focusing on causes of non-acceptance is because it can yield important practical lessons for lessening non-acceptance, I will also briefly discuss some of these lessons and offer some recommendations that reasonably arise from them.

\section{Definitions}

Many authors have pointed out that much confusion around the topic of evolution can be traced to terminology (Thomson 1982; Kugler 2002; Moore et al. 2002; Thompson 2008; Scott and Branch 2009; Mead and Scott 2010a, b), and this complicates the selection of the specific aspect(s) of evolution with which an individual should agree with for it to be judged that they "accept" it (Smith 2010a, b). This confusion starts with the word "evolution" itself, which is frequently used to refer to both descent with modification/ common ancestry (DWM) and mechanisms by which this occurs (mainly natural selection). The term "Darwinism" is similarly used ambiguously (Mayr 1986; Ruse 1992; Scott and Branch 2009; Hull 2011). As evidenced by the initial scientific response to the publication of On the Origin of Species, it is possible to accept DWM without accepting natural selection; as is well-known, for example, by the time of Darwin's death in 1882, virtually all scientists and many non-scientists accepted that life had evolved, but natural selection was not widely accepted as the most important evolutionary mechanism until the 1940s (Hull 1973; Bowler 1983; Ruse 1999). It is likely DWM that most frequently comes to mind when most people hear the word "evolution" (e.g., most modern polls on "evolution" refer to DWM, rather than natural selection, and most images of "evolution" in popular culture [such as cartoons] are to DWM rather than evolutionary mechanisms; e.g., Browne 2001; Clark 2009). As discussed further below, however, acceptance or rejection of DWM may also be strongly affected by misunderstanding of or discomfort with natural selection as an evolutionary 
mechanism (Gould 1974; Bishop and Anderson 1990; Brem et al. 2003).

Even if "evolution" is limited only to DWM, it is clear that non-scientists as a whole do not simply agree or disagree with it but maintain a complex spectrum of views (Evans 2000b; Brem et al. 2003; Ingram and Nelson 2006; Scott 2009; Brown 2010). Education researchers investigating views about evolution have used various survey questions to address this (Rutledge and Warden 1999; Anderson et al. 2002; Ingram and Nelson 2006; Rutledge and Sadler 2007; Shtulman et al. 2008; Southerland and Nadelson 2011), including whether species have changed over time, whether the species in existence today have always existed, whether natural selection is the best explanation for adaptation, whether DWM (with or without natural selection) can account for the appearance of new species, and whether DWM applies to humans. These studies indicate that the general public is often unclear about exactly what they know or accept about evolution.

Discussions of science in general, and evolution in particular, are also significantly complicated by conflicting and inconsistent use and meanings of the terms "belief," "acceptance," "knowledge," and "understanding." As summarized by Smith and Siegel (2004), modern vernacular usage of these words is enormously variable. Within the realm of evolution education, for example, "knowledge" may require "belief" or not, or vice versa (reviewed in Southerland et al. 2001; Smith and Siegel 2004). Some authors use "belief" and "acceptance" more or less interchangeably, with or without comment (e.g., Lawson 1983; Newell 1984; Lawson and Weser 1990; Lawson and Worsnop 1992; National Academy of Sciences 1998; McKeachie et al. 2002; Sinatra et al. 2003). Some argue that "belief" and "knowledge" are effectively indistinguishable (Cobern 1994, 2000). Scientific probability has been defined as "degree of rational belief" or "degree of rationality of a belief" (Popper 1959). Richard Dawkins (1997) proudly states "I believe in the fact of evolution" and defines faith as "belief that isn't based on evidence."

Untangling the linguistic, semantic, and philosophical issues underlying this multiplicity of meaning and usage is truly daunting and well outside the scope of this paper. For my purposes, therefore, I will use the following definitions (see also Fig. 1):

Knowledge - a proposition or conception that represents what a wider community employs as the best, current description of an aspect of reality in the external world and for which a learner must have reasons that provide justification or warrant (cf., Plato's "reasoned" or "justified true belief"; Southerland et al. 2001). Knowledge in this sense is larger than what a single individual holds to be true. Holding some things

\section{BELIEF}

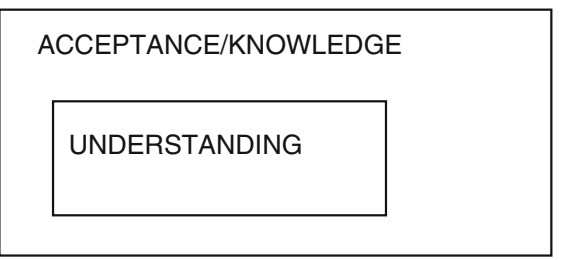

Fig. 1 Schematic representation of the relationship among the terms/ concepts "belief," "acceptance," and "knowledge" as used in this paper

to be true is, of course, necessary for individual survival, but is not sufficient for propositions or conceptions generally treated as "science." Knowledge in this sense might be said to be "acceptance" (see below) by a wider community.

Acceptance - the act or state of agreement that a proposition or conception is true, based on "an examination of the plausibility, persuasiveness, and fruitfulness of the empirical support for the construct" and "not dependent on personal perspectives of the supernatural, nature, and the world, but rather a rational evaluation of that knowledge claim" (Nadelson and Southerland 2010).

Belief - a proposition or conception held by an individual to be true, regardless of whether that individual has particular empirical causes for doing so; beliefs have less rigid criteria than knowledge or acceptance and can be "extrarational" and "have little correspondence with the outside world" (Southerland et al. 2001). Believing is the act or state of agreement with a belief.

Understanding - the act or state of comprehending how it is that a particular proposition or conception operates (whether or not it is held to be true) and the linkages and connections among its constituent elements or aspects (Gauld 2001, as discussed in Smith and Siegel 2004). Understanding is therefore "deeper" or more trenchant than acceptance or knowledge.

If we adopt these definitions, belief is the general term for thinking that a proposition (such as evolution) is true, with acceptance being a more restricted subset (Fig. 1). The terms "non-belief" and "non-believer" can, however, easily be interpreted as implying some kind of equivalence between science and religion (Southerland et al. 2001). At the risk of imprecision and/or inaccuracy, I will therefore use the terms "non-acceptance" and "nonacceptor" below for all instances of not thinking that evolution is true, regardless of whether that is due to analysis of evidence or not. 
In the context of these working definitions of these terms, one major substantive aspect of their relationships should also be mentioned: the question of what the fundamental pedagogical goal of modern science education should be. That is, exactly what is it that educators want students to be able to do at the end of the day (Davson-Galle 2004)?

Some authors argue that the goal of science education should be no more (and no less) than to foster student understanding, with or without acceptance, of "the content of science, the current best explanations of how things work-as well as the nature and methods of science" (Smith and Siegel 2004; see also Cooper 2001; Southerland et al. 2001; Alters and Nelson 2002). In this view, it is "morally questionable" to require that students believe or accept a particular scientific proposition because it amounts to "scientism" ["the position that all of a person's beliefs should be based on science" (Smith and Siegel 2004)] and potentially infringes on student religious beliefs and/or autonomy (Southerland et al. 2001; Smith and Siegel 2004). Science education should, in this view, "aim at knowledge and understanding of the theory, and let student belief fall where it may" (Smith and Siegel 2004). Indeed, several studies report that students can successfully demonstrate an ability to describe and apply modern evolutionary theory (e.g., on exams) but then state that they do not accept (or "believe") it (e.g., Bishop and Anderson 1990; Lord and Marino 1993; Demastes et al. 1995a, b; Chinn and Samarapungavan 2001; Ingram and Nelson 2006; Lombrozo et al. 2006). To "those who find it inadequate or unsatisfying that the science teacher should leave student belief aside," suggest Smith and Siegel [2004], there may be some "comfort in realizing that belief typically follows understanding, and that, when it doesn't, that disconnect is usually the result of strongly held convictions that science by itself cannot undermine or adequately address."

Other authors, however, strongly disagree with this approach, and maintain that the primary goal of science education should be "changing student beliefs," specifically the abandonment by students of all nonscientific explanations for the phenomena that evolution by natural selection seeks to explain (Lawson and Worsnop 1992; Alters 1997; Chinn and Samarapungavan 2001). In this view, any real understanding of a scientific proposition (such as evolution) cannot be achieved without acceptance of that proposition as true, and lack of acceptance can be a serious barrier to scientific understanding (Lawson 1983; Cobern 1994; McKeachie et al. 2002; Davson-Galle 2004). There is a strong practical (and philosophical) argument in favor of this point of view: most people would like trained scientists to be correct. Although "teachers are often uncomfortable with viewing themselves as persuaders...almost everyone would prefer that civil engineers actually believe the wellestablished principles of building safe bridges that they learn in their engineering classes" (Chinn and Samarapungavan 2001), and most people would likely prefer a physician who actually accepts the truth of most of what he or she learned in medical school, rather than just going through the motions as though they thought it was true (Pennock 1999; Ruse 2001).

Finally, it has also been argued that students cannot accept a theory unless they develop at least some understanding of it (Lawson and Worsnop 1992; Sinatra et al. 2003). At the other extreme, some students can accept evolution but not demonstrate strong understanding of it (Bishop and Anderson 1990; Lord and Marino 1993; Sinatra et al. 2003; Cavallo and McCall 2008; Deniz and Donnelly 2011; see Wiles et al. 2011 for a review). In this paper, I leave this extremely important issue unresolved.

\section{Causes of Non-acceptance}

\section{Insufficient/Incorrect Factual Knowledge}

The hypothesis that non-acceptance of a particular scientific conclusion, theory, or idea is mainly due to insufficient knowledge is intuitively appealing, especially to educators, who usually view their job to be communication and explication of such conclusions, theories, and ideas. Some level of familiarity with empirical "facts" is obviously required for rational acceptance of any idea about the material world (e.g., if you don't know that the Second World War came before the Vietnam War, twentieth century American history doesn't make much sense). There is, indeed, considerable evidence that at least some non-acceptance of evolution is due to lack of adequate familiarity with and/or understanding of the "facts"- the evidence that evolution itself has occurred and/or what modern evolutionary theory actually claims.

At the most general level, several studies have found that level of education is positively correlated with acceptance of evolution (People for the American Way Foundation 2000; Brumfiel 2005), although this correlation seems to apply less for "Intelligent Design," many advocates of which are highly educated (Shanks 2004; Scott 2009). More specifically, recent polls of Americans indicate low basic knowledge of science in general, and biology and geology in particular.

For example, only $38 \%$ of American adults agree that humans have more than half of their genes in common with chimpanzees; fewer than half of American adults can provide a minimal definition of the role of DNA in heredity (Miller et al. 2006; Miller 2010). Less than a third of 
respondents in most surveys give accurate descriptions of natural selection (Brumby 1984; Bishop and Anderson 1990; Greene 1990; Demastes et al. 1995a, b; Ferrari and Chi 1998; Anderson et al. 2002; Nehm and Reilly 2007; Gregory 2009; Nehm et al. 2009). Knowledge of the fossil record is similarly poor; only $59 \%$ of respondents to a recent poll, for example, know that the earliest humans and dinosaurs did not live at the same time (California Academy of Sciences 2009). Catley and Novick (2009) report "startlingly large" variation among college students in their knowledge of the relative and numerical timing of various events in the history of life (e.g., the age of the Earth, dinosaur extinction, the appearance of the genus Homo) (see also Cotner et al. 2010; Allmon et al. 2011 and references therein). Nelson (2008) writes that students in his college courses "thought of fossils as rare and more or less haphazardly scattered across the landscape," rather than providing abundant and consistent evidence of the chronology of life.

Given this low level of general scientific literacy, it is not surprising that many people think that empirical evidence for evolution is sparse. For example, surveys of American college students have found that $20-50 \%$ think that there is abundant credible evidence against evolution, that modern evolutionary theory lacks "a valid scientific foundation," and/or that "evolution is far from being proven scientifically" (Lord and Marino 1993; Cunningham and Wescott 2009; People for the American Way Foundation 2000) (as Shtulman 2006 notes, "those who do not endorse the claim that Darwin's theory of evolution has been well supported by evidence tend to endorse the alternative claim [i.e., that Darwin's theory of evolution has not been well supported by evidence] rather than plead ignorance"). Thus, when creationists claim that there are "no intermediate fossils" (Denton 1986; Johnson 1991; Gish 1995), when in fact they are abundant in the geological record (Padian et al. 1999; Prothero 2007), a largely uninformed public accepts such statements. As Hofmann and Weber (2003) point out, if you don't know much about the fossil record or genetics, then critiques of evolution such as Wells (2002) can sound quite plausible. Similarly, Asghar et al. (2007) report that lack of specific content knowledge among teachers has a negative effect on the decision of whether to include evolution in their curriculum.

Students and the general public also hold a wide variety of specific misconceptions about what modern evolutionary biology says (Brumby 1984; Bishop and Anderson 1990; Ferrari and Chi 1998; Antolin and Herbers 2001; Woods and Scharmann 2001; Alters and Nelson 2002; Anderson et al. 2002; Isaak 2006; McVaugh et al. 2011; Shtulman et al. 2008; Wiles et al. 2011). For example, many think that new functional traits appear in organisms when they are needed; that evolution consists of the transformation of an entire species' underlying essence; that it necessarily implies "randomness," "progress," or increasing complexity; or that it is mathematically improbable or violates the second law of thermodynamics. Such misunderstandings affect acceptance of evolution because if many people think that they understand evolution, when in fact they do not, they may not only "fail to appreciate how empirical evidence bears on evolutionary claims" (Lombrozo et al. 2006) but they can also be misled by critiques of these mistaken views (Cunningham and Wescott 2009; Jakobi 2010; McVaugh et al. 2011). That such misconceptions are at least occasionally important barriers to accepting evolution is indicated by studies in which acceptance is increased by "presenting students with a direct comparison of various naïve misconceptions associated with creationism to explanations which are more consistent with scientific evidence" (Alters 2005; see also Alters and Nelson 2002; Ingram and Nelson 2006; Nelson 2007; Verhey 2005; Wilson 2005; Wiles et al. 2011).

Another important area of "insufficient knowledge" of evolution is that non-acceptors may not understand just how useful evolution is as a scientific hypothesis. One reason scientists accept a theory is because it explains many, often diverse, observations. They may even accept ideas that might otherwise seem counterintuitive or not directly observable if they explain enough observations (e.g., relativity, plate tectonics). Non-acceptors may not be aware of how powerful evolution is as a theory, not only in how it famously "makes sense" of all of biology (Dobzhansky 1973) but also explains observations in disparate areas of applied biology of great relevance to human welfare, from domestication to medicine (Wilson 2005, 2007; Mindel 2006; Antolin 2009; O’Brien et al. 2009; Hendry et al. 2011).

\section{Inadequate/Incorrect Understanding of the Nature} of Science

Scientists and educators alike frequently state that one of the biggest causes of non-acceptance of evolution is a widespread lack of understanding of the "nature of science" (NOS; Nickels et al. 1996; McComas et al. 1998; National Academy of Sciences 1998; Nelson et al. 1998; Rudolph and Stewart 1998; Rutledge and Warden 2000; Alters and Alters 2001; Pigliucci 2002; Farber 2003; Trani 2004; Scharmann et al. 2005; Lombrozo et al. 2006, 2008; Pigliucci 2007; Scott 2009; Thagard and Findlay 2009; Ellis 2010; Kampourakis and McComas 2010; Cho et al. 2011). Scott (2009) notes that in the landmark 2005 court case on teaching intelligent design in public school classrooms (Kitzmiller v. Dover), "All of the plaintiffs' expert witnesses spoke to the question of the nature of science..." [lack of understanding of NOS cannot be the only 
explanation for non-acceptance of evolution, since it does not explain "why antipathy towards the theory of evolution is stronger than to other scientific theories, such as the theory of gravity" (Evans 2008)].

Enhancing learners' understanding of NOS is a longstanding goal of science education in general (e.g., Moore 1993; National Academy of Sciences 1998; Cobern 2000; Lederman 2004; McDonald 2010; Yacoubian and BouJaoude 2010). Part of the problem, however, is that scientists and philosophers of science themselves disagree about what exactly the nature of science is (Alters 1997; Abd-ElKhalick et al. 1998; Rudolph 2000; Lederman 2004; AbdEl-Khalick 2005; Cho et al. 2011; Duschl et al. 2011). Traditionally, "the scientific method" has been presented (especially in classrooms) as a "fairly rigid sequence of steps, followed like a recipe and leading to irrefutable results" (McComas et al. 1998). This long-standing hegemony of realism in science has, however, coexisted uneasily, almost since science began, with another very different line of thought, which emphasizes the similarities between science and other human pursuits, such as subjectivity, bias, and social influence, and argues that despite the evident success of science, we are not nearly as certain of its conclusions as we like to think. These views have gone under many names, including relativism, skepticism, deconstructionism, constructivism, and postmodernism (Golinski 1998). Thus, there is a central paradox to science: Humans appear to have the ability to sense and comprehend at least some "real" aspects of the world around us, yet this ability is not perfect, and what we make of the world is, therefore, often shaped as much or more by our feelings, hopes, prejudices, fears, desires, and preconceived ideas as it is by empirical observations and rigorous logic (e.g., Bridgman 1955; Golinski 1998; Chalmers 1999; Gauch 2003; Haack 2007; Lombrozo et al. 2008). In this view, real science as scientists do it includes an array of social interactions and "dialectical processes that shape the role theory, evidence, explanation, and models have in the development of scientific knowledge" (Duschl et al. 2011). As nicely put by Brown and Gibson (1983), "most practicing scientists know that a scientific inquiry is much more like working on a puzzle or being lost in the woods than baking cookies or following a roadmap."

Much of the relativist/realist debates of the past couple of decades, sometimes referred to as the "science wars" (Parsons 2003), have died down, and some relatively clear standards for teaching NOS have been put forward during this time (e.g., Lederman 1992; Nickels et al. 1996; McComas et al. 1998; National Academy of Sciences 1998). Yet the relative roles of objectivity, certainty, social embeddedness, gender bias, and other factors in the process of science, and the best way to teach its apparently inescapably paradoxical character, remain complex, controversial, and unresolved (e.g., Weinberg 2001; McComas 2002; Blystone and Blodgett 2006; Haack 2007; Lombrozo et al. 2008; Yacoubian and BouJaoude 2010). This lack of consensus about what NOS actually is and especially about how it should be taught has important implications for acceptance of evolution. For instance, individuals who think that science is about absolute certainty may not understand when scientific conclusions change in light of new data or revised ideas (Chinn and Malhotra 2002). Individuals who learn that all science is a social construct may reject scientists as just another vocal special interest (Sokal 2008).

Another common example of misunderstanding of NOS in evolution education is the importance of what is usually called simply "inference" [but, more accurately, "inductive inference" (Ziman 2000)], that is, the extrapolation from observations to a larger pattern that is not observed directly. One of Darwin's greatest innovations was to argue (following the approach advocated by his friend Charles Lyell) that one could use observed small-scale change in organisms to infer (and explain) large-scale change. The first chapter of the Origin of Species, for example, is mainly about pigeons because Darwin wanted to convince his readers of the validity of extrapolating from small changes produced by artificial breeding over short time intervals to larger changes produced by natural selection over geological time [this is sometimes discussed as an example of Darwin's use of metaphor, which is also a means of extending reasoning from one idea to another (Young 1985; Ruse 2005; Pramling 2008; Gregory 2009b; Largent 2009)]. Change under domestication and similar phenomena familiar to most people today, such as antibiotic and pesticide resistance, or changes in the HIV virus (Freeman and Herron 2007; Gregory 2009b) are frequently acknowledged (as they must be) by creationists, who otherwise reject the validity of extrapolating from such "microevolution" to "macroevolution" (Johnson 1991). On one hand, such rejection is consistent with intuition. Surveys of both students and the general public similarly show greater acceptance of microevolutionary than of macroevolutionary concepts (Poling and Evans 2004) because the former is "directly observable" whereas the latter is not [interestingly, increasing the teaching of macroevolution seems to result, at least occasionally, in increased acceptance of evolution (Nadelson and Southerland 2010; Padian 2010; see discussion in Smith 2010b), perhaps because it involves explicating more specific examples from the fossil record]. On the other hand, rejecting the extrapolation from microto macroevolution is inconsistent with the application of inference common to all science. For example, if we drop a ball, we can measure how fast it falls; we can then use this result to apply to other falling objects. All scientific 
hypotheses are essentially about applying what is known (from observation and/or experiment) to what is unknown. If we had to personally observe everything in science to be certain of it, no progress could ever be made in our understanding of the world.

A similarly major issue around NOS and creationism is the application of materialism. Advocates of ID, for example, claim that they are challenging the "philosophy of scientific materialism, not science itself" (Discovery 2003). This is a useful rhetorical approach in their public statements as it allows them to appear moderate and reasonable and unthreatening to fields such as medicine, engineering, and agriculture that have obvious personal and economic benefits. Such critics of evolution therefore apparently allow extrapolation (of material causes) to areas that they accept, but not to areas that they do not (where they claim that supernatural causes are required). They may claim that they use science and the technology that comes from it, just like everyone else: "The possibility that divine intervention may occur...emphatically does not imply that all events are the product of an unpredictable divine whimsy" (Johnson 1995). Yet, as Pennock (1999) notes, they never explain what the methods are for determining when divine intervention is and is not to be considered potentially responsible for a particular event. While acknowledging that some theologies may describe God as capriciously and frequently intervening in the natural workings of the world, some creationists argue that a correct Christian view "holds that secondary causality (causation by natural laws) is God's usual mode and primary causality (direct divine acts or miracles) is infrequent, comparatively speaking" and that science should not defer to such primary causality "willy-nilly" (Moreland 1989, quoted in Alters and Alters 2001). But, again, there is no definition of "willy-nilly." This inconsistency - which Nanda (2003) has called "reactionary modernism"- cuts to the heart of the scientific method, which must consider only material causes for material phenomena. Numerous defenders of evolution have tried to approach this issue by arguing for the importance of distinguishing "methodological" materialism from "philosophical" or “ontological" materialism (Pennock 1999; Scott 2009).

\section{Religion}

Historically, religious objections were perhaps the strongest among the immediate negative reactions to the publication of the Origin (Hull 1973; Farley 1974; Ruse 1999; but see Livingstone 1984), and religious belief is widely regarded by education researchers as a major reason for modern nonacceptance of evolution (Bishop and Anderson 1990; Osif 1997; Lawson and Worsnop 1992; Sinclair and Pendarvis 1997; Aguillard 1999; Downie and Barron 2000; Antolin and Herbers 2001; Evans 2001; Brem et al. 2003; Sinatra et al. 2003; Trani 2004; Mazur 2005; Miller et al. 2006; Nehm et al. 2009; Woods and Scharmann 2001; Jakobi 2010; Pazy-Miño and Espinosa 2010; Tracy et al. 2011). Specifically, evolution appears to call into question the literal truth of some religious scripture, not only in the Judeo-Christian Bible (Cantor and Swetlitz 2006; Robbins and Cohen 2008) but also the Quran (Edis 2007) and Hindu texts such as the Bhagavad Gita (Brown 2010). More generally, however, evolution is seen by many critics as "more than a scientific theory-it is a powerful medium for the propagation of materialism and atheism...associated with a variety of social ills: racism, moral relativism, abortion, pornography, and the breakdown of the family unit..."; for many, "acceptance of evolution necessarily entails commitment to materialistic atheism..."; evolution, in this view, is "not just science, but an anti-religious ideology" (Harrison 2010).

Non-acceptors of evolution frequently express the view that acceptance of evolution would entail the acceptance of a host of ideas that they find unacceptable: that life has no purpose or meaning; that races or ethnic groups are inherently different; that there can be no supreme being, afterlife, or spiritual rewards; that evolution means that people are "nothing more than animals" and therefore hardwired for selfishness and ruthless behavior; and that there can be effectively no free will or self-determination. Research has specifically found that creationists who are exposed to evolutionary theory, including its implication of a close connection between humans and other animals, have increased thoughts of mortality (Tracy et al. 2011). Individuals frequently respond to such existential threats by "becoming more accepting of a theory that offers a greater sense of meaning by depicting human life has having ultimate purpose..." (Tracy et al. 2011). For all of these reasons, the purposeless, materialistic aspect of Darwinian evolution is highly repugnant to many people (Gould 1974). Intelligent design proponent Phillip Johnson's fundamental objection to evolution, for example, is precisely what he sees as the pernicious effects of materialism (Johnson 1995; see Pennock 1996, 1999). Similar feelings are likely widespread. As Thagard and Findlay (2009) put it: "People do not just think that evolution by natural selection is false; they want it to be false. Even people who believe in evolution may admit that they want it to be false!"

Many evolutionists have argued that evolution necessitates none of these conclusions (Miller 1999; Scott 2009; Mead and Scott 2010a, b; see Allmon 2009 for a review), and - as widely emphasized by evolution advocates - most "mainstream" Christian denominations have accommodated evolution [Martin 2010; even though such accommodation has its critics on both the religious and anti-religious sides 
(Allmon 2009)]. Several authors have suggested that if students knew that such accommodation is possible, it might lessen their resistance to evolution (Colburn and Henriques 2006; Scott 2009). Yet such messages are apparently not widely heard by the general public, perhaps in part because of contrary views loudly voiced by other evolutionists that religion and evolution are wholly incompatible (e.g., Dawkins 2006; Dennett 2006; Provine 2006; Coyne 2009b). Indeed, at least a few studies of undergraduates have found that increased exposure to evolution produced decreased acceptance and/or increasingly negative perceptions regarding the consequences of accepting it (Brem et al. 2003; Sinatra et al. 2003; Lovely and Kondrick 2008). For example, in his course on evolution for nonmajors at Cornell University which he has taught for more than 20 years, William Provine has found that between the beginning and end of the course, not only does the percentage of students accepting evolution go up but so does the percentage firmly rejecting it (W. Provine, personal communication).

\section{Psychological Obstacles}

A large and rapidly growing body of psychological research points strongly to a major role for psychological factors in how and why particular ideas are more readily adopted than others, and such factors constitute a significant but frequently underrecognized element of non-acceptance of evolution. They can be grouped into at least two categories. First are the numerous processes by which the human mind appears to overrule what the senses are telling it and which lead to decisions that appear counter to the perceived empirical state of the physical world. Second are specific, apparently innate psychological characteristics and biases in how humans interpret the world.

As much as logic and rationality contribute to human thought and despite the rise in the influence of science in modern society, human reasoning is still suffused with "affective" influences-emotion, wishes, hopes, beliefs, faith, illusions - that fly in the face of the "facts" (e.g., Harvey 1992; Sutherland 1994; Pohl 2004; Gordon et al. 2005; Fine 2006; Kida 2006; Bering et al. 2011; Mooney 2011; Shermer 2011; Watts 2011). One of the explanations for such psychological devices appears to be to minimize cognitive dissonance - the psychological discomfort caused by mutually contradictory cognitions - which leads a person to avoid or ignore additional information likely to increase the dissonance and to seek out additional information that will reduce the dissonance (Harmon-Jones et al. 1999). Cognitive dissonance has been suggested as an explanation for or contributor to a host of human behaviors that go against what a purely rational or logical assessment of available empirical information would suggest, including optimism, wishful thinking, gambling, entrepreneurship, and many other things that people do every day (Griffiths 1990; Liang and Dunn 2008; Krizan and Windschitl 2009 and references therein). Such behaviors, of course, sometimes are highly beneficial. Optimism, for example, is frequently associated with better physical health, more persistence in educational efforts and personal relationships, and resilience to stressful life events and may be, at least to some degree, "hard-wired" into the brain (Armor and Taylor 2002; Carver et al. 2010; Barefoot et al. 2011; Sharot 2011). Yet there is also evidence that optimist tendencies can lead to engaging in risky behaviors, which can be hazardous to health and well-being (e.g., Lovallo and Kahneman 2003; Isaacowitz 2005; Jansen et al. 2011; Sharot 2011).

More significant intentional or unintentional psychological dissociation, labeled by psychologists as "self-delusion" or "self-deception," allows people to persuade themselves to believe (or accept) what they rationally "know" is not so (Fingarette 1969; Audi 1988). Psychologists disagree, however, on exactly what causes or allows this phenomenon (Trivers 1985; Scott-Kakures 1996; Lazar 1999 and references therein). One interpretation is that although the self-deceiver holds two incompatible beliefs and at the same time, one of the beliefs is somehow not consciously "noticed," thus allowing the two to avoid direct comparison and so the realization of their incompatibility. In this sense, most people hold numerous self-contradictory beliefs, "if only because we cannot see far enough into the implications of each of our beliefs" (Fingarette 1969). As Shermer (2007) puts it: "Smart people believe weird things because they are skilled at defending beliefs they arrived at for non-smart reasons."

Although I am not aware of any psychological research that specifically addresses the issue of cognitive dissonance and evolution, it seems reasonable to suggest that it is, at least in part, in an effort to avoid cognitive dissonance that individuals committed (for whatever reason) to notaccepting evolution will-by one or more mechanisms like those described above - resist embracing, or even encountering, evidence or arguments that evolution is true.

How we think may also affect what we accept. Woods and Scharmann (2001) found a significant correlation between logical thinking skills and acceptance of evolution. Sinatra et al (2003) similarly reported that students with more sophisticated and flexible styles of knowledge and learning were more likely to accept evolution. In several papers, Lawson and colleagues found that "reasoning ability" was a strong predictor of the number of misconceptions held by seventh grade students about genetics and natural selection, and that "less skilled reasoners" were more likely to have nonscientific beliefs initially and less likely to change those beliefs after instruction (Lawson 1985; Lawson and Thompson 1988; Lawson and Weser 1990). 
Numerous studies have suggested that evolution runs counter to particular aspects of human psychology. Several authors, for example, have noted that evolution is in some ways counterintuitive (Mayr 1982; Evans 2008; Williams 2009; Wiles 2010); for example, evolutionary thinking states that the apparently stable present world of everyday experience is a result of ceaseless change and that complex structures arise from less complex without a conscious designer. Some of these "everyday" modes of thinking may be innate patterns and modes of understanding, which coincidentally frequently tend to resonate better with creationist views (Evans 2000b, 2008; Poling and Evans 2004). These patterns or biases appear very early in human development and may constrain "human cognition such that creationist ideas are attractive and easier to spread, whereas evolutionary ideas are less contagious" (Evans 2008). Nonbelief in evolution, therefore, may well begin "with the natural, intuitive development of 'creationist' ideas as a very young child" (Williams 2009). Among such potential cognitive biases, "two staples of Western philosophical thinking" in particular "serve to inhibit the expression of natural explanations for the origins of species" and evolutionary change (Evans 2001): essentialism and teleology.

Essentialism The idea that all living things are separate, stable, and unchanging [and its corollary that a species' outward appearance and behavior are determined by a hidden causal power or "essence" (Shtulman 2006)] appears to have deep psychological sources in humans (Samarapungavan and Wiers 1997; Evans 2000a; Poling and Evans 2004; Shtulman 2006, 2011; Shtulman and Schulz 2008). Such views are clearly at odds with the "variational" or "populational" conceptions of the Modern Synthetic theory of evolution (e.g., Mayr 1982). It is particularly problematic, however, for the acceptance of macroevolutionary processes; while "essentialist constraints can be modified to accept microevolutionary processes... (they) have to be radically transformed to endorse macroevolution" (Poling and Evans 2004). This is why essentialism has frequently been identified as one of the principal historical obstacles to accepting evolution prior to Darwin (Mayr 1982).

Essentialism is related to other psychologically difficult concepts that must be confronted in understanding modern evolutionary explanations. Evolution by natural selection, for example, is inherently statistical and involves probabilistic changes in genes and species, and many authors have argued that such statistical thinking is unfamiliar and difficult for most people (Hacking 1975; Birnbaum et al. 1990; Thagard and Findlay 2009). Evolutionary explanations also require appreciation of the related concepts of emergence and hierarchy, which also do not come naturally to most people (Chi 2005; Slotta and Chi 2006; Thagard and Findlay 2009; Meisel 2010). Emergent processes are those in which large effects result from smaller operations that are qualitatively different (Holland 1998; Reid 2007). Unlike simple mechanical systems, in which changes in the whole system can easily be seen to result from the motions of its constituent parts, in emergent processes, qualitatively new changes come about because of many small interactions at lower hierarchical levels. "Not only is evolution an emergent process on the Darwinian account, but thinking is also an emergent process on the account currently being developed in neuroscience...Thus the human mind is an emergent process resulting from an emergent process!" (Thagard and Findlay 2009). Hierarchy is similarly counterintuitive because it cannot be seen directly, but is inferred based on the relationships of objects (Grantham 1995, 2001). Hierarchy in evolution is commonly presented in phylogenetic diagrams, and the ability to comprehend evolutionary relationships has come to be referred to as "tree thinking," which many authors argue is frequently very difficult to grasp and to teach (Baum and Offner 2008; Gregory 2008; Sandvik 2008; Meisel 2010).

Teleology Teleological thinking-the concept that natural objects have some kind of goal direction, provided by either a self-directing vital power or divine source, which is the cause of their functionality - has a long and problematic history in evolutionary biology. Most evolutionists maintain that Darwinian natural selection is inherently nonteleological because it is not goal-directed and does not anticipate the future (Mayr 1988; Futuyma 2009). Others point out that evolutionary biologists themselves are responsible for the persistence of teleological language and thinking (Weiss 2002; Reiss 2009; González Galli and Meinardi 2011). For example, Darwin used language that can be termed teleological (Lennox 1993), and the ubiquitous reference to natural selection as a "force" or "mechanism" is evidence of persistent teleological thinking in modern evolutionary biology (Nehm et al. 2010; Provine 2001; Reiss 2009; González Galli and Meinardi 2011; but see Ruse 2005).

More generally, the widespread idea that animate behavior and adaptation are goal- or purpose-directed has been identified by numerous authors as a major source of misunderstanding about how evolution by natural selection works (Jungwirth 1975; Deadman and Kelly 1978; Clough and Wood-Robinson 1985; Tamir and Zohar 1991; Pedersen and Halldén 1992; Demastes et al. 1995a; Jensen and Finley 1995, 1996; Kelemen 1999a, b, c; 2011; Moore et al. 2002; Kampourakis and Zogza 2008; Evans et al. 2010). Teleology implies that evolutionary change happens by the transformation of the same basic quality or essence of all individuals in a species, as opposed to changes in the relative frequency of individ- 
uals with different characteristics within populations, and so is utterly incompatible with Darwinian processes (Shtulman 2006, 2011).

As with essentialism, this intuitive inclination toward purpose-based teleological explanations appears to originate early in childhood and, unless it is challenged, persist into adulthood (Evans 2000a, 2001, 2008; Poling and Evans 2004; Kelemen 1999a, b, c, Kelemen 2011). This may occur because, lacking knowledge of scientifically valid physical causal explanations of natural phenomena, young children "compensate by drawing on their knowledge of a domain that they know well," i.e., the intentionally designed artifacts around them (tools, clothes, etc.); they thus "plug their explanatory gaps by treating nature as though it has been made for a purpose by some kind of underspecified non-human agent" (Kelemen 2011). This is not because children cannot understand physical causes (it has been demonstrated that infants can discriminate physical/mechanical causes from intentional causes); rather, children appear to "intuitively analogize to the intention-based artifact domain... and evidence a bias to privilege intentional explanations of events" (Kelemen 2011). This innate response has been called "the intentionality bias" (Rosset 2008; see also Wolpert 2006).

\section{Political/Social Influences}

Political and social influences may at first seem like what are herein referred to as "ultimate/secondary" causes for non-acceptance of evolution (Table 2) because they provide the milieu in which other factors act, rather than acting directly to cause particular behaviors or mental conceptions. Yet this is probably an oversimplification because social and political factors can, at least occasionally, act directly on individuals and affect their conceptions about the world.

For example, rejection or acceptance of an idea may depend not only on its empirical, philosophical, or psychological characteristics but also on who suggests, supports, or attacks it. It may be difficult, for example, to reject a view provided by parents or another authority figure because this may, in the mind of the recipient, be equivalent to rejection of that individual or institution (Demastes et al. 1995a; Woods and Scharmann 2001; Williams 2009; Wiles et al. 2011). This can readily translate into politics. The process of deciding who is a legitimate authority on particular topics (such as science) can be socially or politically determined; an individual's political affiliation and views about morality and social order, for example, strongly predict whom they consider to be a legitimate scientific expert (Kahan et al. 2011; Mooney 2011). Thus, some people may not accept evolution because it is associated in their minds with a sociopolitical agenda that they find otherwise unacceptable.

In the U.S., evolution is highly politicized compared to other developed countries (Forrest and Gross 2004; Gibson 2004; Shanks 2004; Miller et al. 2006; Berkman and Plutzer 2010) and, as Woods and Scharmann (2001) put it, "acceptance of evolutionary theory will continue to engender frustration in the United States as long as the cultural and/or political milieu dictates that it must be so." Political orientation is nearly as powerful as education in predicting evolutionary belief in Americans; the alignment of individuals, groups, and political parties concerning evolution closely resembles those found with same-sex marriage, abortion, and other controversial "social" issues (Berkman and Plutzer 2009). Self-identified political liberals are more likely than political conservatives to accept that humans evolved from earlier species (Mazur 2005), and the more conservative a person's political views, the less likely he or she is to accept a great age of the Earth (Cotner et al. 2010). In the 1990s, the Republican platforms in seven states included explicit demands for the teaching of "creation science" (Paterson and Rossow 1999; Miller et al. 2006). Such political effects on evolution acceptance are not limited to the U.S. Although Hindu creationism may be motivated by belief that scriptures such as the Bhagavad Gita are definitely authoritative, it also has significant roots in Indian reaction to British colonial rule (Brown 2010).

\section{Discussion}

Despite the enormous progress that has been made in evolution education over the past 20 years or so, we still lack a comprehensive framework and strategy for how evolution education can engage with the full spectrum of obstacles to acceptance/understanding of evolution in and out of schools, which might allow truly significant improvements on a national or international scale to be realized.

Previous work reviewed above makes clear that the solution to this challenge lies not just in further resolution of the "religion vs. science" controversy; indeed, this issue may have no "universally acceptable rational solution" (Shanks 2004; see also Allmon 2009). Neither does it lie only in presentation of a more extensive catalog of empirical evidence or case studies for descent with modification or natural selection; people come to evolution with too much psychological baggage. It does not lie just in better engagement with prior conceptions or better presentation of the nature of science; neither students nor the general public are sufficiently familiar with the empirical facts of the natural world. Nor is it only in the overcoming of a single type of psychological obstacle; as is true for all 
fields of science, studying evolution requires adherence to "a way of knowing" that, for a wide variety of reasons, does not necessarily come naturally to all people, meaning that learning and teaching about it must involve some degree of "conceptual change" (Sinatra et al. 2008), which is simply difficult for human beings to undertake.

The solution lies in all of these. Yet every teacher cannot engage all of the causes listed in Table 1 in every class or even semester. What then will a successful "comprehensive framework" for improving acceptance/understanding of evolution look like? I do not presume to provide an answer here, only to offer a few conclusions based on the foregoing discussion:

1. More research. Determining which causes are more responsible for non-acceptance of evolution, in general or in any individual case, will require much more research on why and when different people accept or do not accept evolution when they are exposed to it, especially the role of "scientific" vs. "affective" causes for non-acceptance. Arranging experiments to adequately test different factors is challenging, largely because of the difficulties of identifying and testing populations that differ only in the desired variables and not in others (Wiles et al. 2011). Further, we appear to be just at the beginning of understanding the psychological barriers to accepting evolution, and improvement in education will require continued improvement in such understanding, both in children and adults (Evans 2000a, b, 2008).

2. Identifying student preconceptions. Most obviously, a more explicit approach to identification and understanding of the causes for non-acceptance of evolution (such as presented in Table 1) should support the oftenstated goal of understanding "where students are" prior to implementing the kind of approaches frequently advocated for teaching evolution, including encouraging students to compare their preconceptions with scientific ideas, identify limitations in their own ideas, and construct more scientifically valid understandings. Just recognizing the complexity of the situation could be a major improvement. My own experience has been that, to the degree they think about it at all, many instructors assume that non-acceptance of evolution in their students is due to some simple combination of religion and low scientific literacy; the former is usually seen as not a teacher's business, while the latter can be an excuse to revert to an old-fashioned, "more content" style of teaching that is otherwise gradually acquiring a bad name.

3. Implementation. Even when we have this better understanding, its application in actual educational settings will require a high level of integration of multiple educational perspectives and academic disciplines (Wilson 2005, 2007; O'Brien et al. 2009), much more than is normal in most formal educational settings.

4. Informal science education venues. Even if classroom evolution education was much more successful than it is now, that would likely not be enough to raise levels of Americans' acceptance and/or understanding of evolution to where they should be. Americans spend the great majority of their lives outside of school (National Research Council 2009; Falk and Dierking 2010); they must therefore continue to have meaningful opportunities to hear and learn about evolution long after they leave school, and these opportunities must navigate the same complex of causes for nonacceptance as does classroom teaching. This may be especially challenging for some informal education venues, such as museums, zoos, parks, and aquaria, which may have abundant raw material to illustrate the results of evolution but also typically have the attention of audiences for very short periods and at times when they may be as or more interested in leisure than in learning. How, for example, can a museum exhibit on the fossil evidence for evolution take into account the psychological, religious, and/or sociopolitical factors that may be influencing the thinking of its visitors? Simply asking such questions (Evans et al. 2010; Allmon et al. 2012) may be an important step in the right direction.

\section{Concluding Remarks}

One of the main motivations behind this paper was my growing perception that what appeared to be an adequate understanding of the causes for and solutions to the widespread non-acceptance of evolution was not in fact a solid consensus. Everyone knows that religious beliefs are often associated with resistance to evolution. Yet when confronted with the practical task of teaching a particular class or designing a particular museum exhibit, it quickly becomes clear that the actual range of potential causes for non-acceptance is much larger, that neither religion nor biology is necessarily the right place to start, and that simply assuming that we know what our audience thinks and why can lead our educational efforts seriously astray. Unexpected evidence that I was correct about this lack of consensus came from comments by two reviewers of this paper, who stridently objected to various of my conclusions with words to the effect that "everyone knows," for example, that there is no demonstrated relationship between NOS and acceptance of evolution; that terminological 
confusion and factual misunderstanding are at most only minor contributors to non-acceptance; that there is no disagreement in the science education community about NOS; that there is no empirical support for the idea that teaching macroevolution will increase acceptance of evolution; that there is no support for the idea that increased exposure to evolution can produce decreased acceptance; and that "good teachers" will automatically know how to deal with any and all obstacles to their students accepting evolution. Despite these statements, my review (and rereview) of the large and growing evolution education literature, together with my long experience teaching evolution in a wide variety of settings, demonstrates that all of these statements are at best oversimplifications and at worse simply untrue. That these reviews came from very distinguished individuals in the field of evolution education reinforces my basic conclusion: that the appallingly widespread rejection of evolution is a much more complicated problem than most scientists, educators, journalists, and legislators think it is, and that those who care about reversing this situation should do more to take this complexity into account as we seek to come up with new and more adequate solutions.

Acknowledgments I am grateful to Barbara Crawford, Niles Eldredge, Irby Lovette, Will Provine, Rob Ross, and two anonymous reviewers for helpful comments on previous drafts and to Jennifer Thompson and Maya Weltman-Fahs for assistance with references.

\section{References}

Abd-El-Khalick F. Developing deeper understandings of nature of science: the impact of a philosophy of science course on preservice science teachers' views and instructional planning. Intern J Sci Edu. 2005;27:15-42.

Abd-El-Khalick F, Bell R, Lederman N. The nature of science and instructional practice: making the unnatural natural. Sci Ed. 1998;82:417-36.

Aguillard D. Evolution education in Louisiana public schools: a decade following Edwards v. Aguillard. Am Bio Teach. 1999;61:182-8.

Allmon WD. The "God spectrum" and the uneven search for a consistent view of the natural world. In: Schneiderman JS, Allmon WD, editors. For the rock record: geologists confront intelligent design. Berkeley: University of California Press; 2009. p. $180-239$.

Allmon WD, Ross RM, Kissel R. No more important lesson to teach: presenting geologic time in museum exhibits. Geosphere. 2011; (in review)

Allmon WD, Ross RM, Kendrick DL, Kissel R. Using museums to teach undergraduate paleontology and evolution. In: Teaching paleontology in the twenty-first century: resources for teaching paleontology at the undergraduate level. Yacobucci MM, Lockwood R, editors. The Paleontological Society Papers; 2012 (in press).

Alters B. Whose nature of science? J Res Sci Teach. 1997;34:39-55.

Alters B. Teaching biological evolution in higher education. Methodological, religious, and non-religious issues. Sudbury: Jones \& Bartlett; 2005.
Alters BJ, Alters SM. Defending evolution. A guide to the creation/ evolution controversy. Sudbury: Jones and Bartlett; 2001.

Alters B, Nelson C. Teaching evolution in higher education. Evolution. 2002;56:1891-901.

Anderson D, Fisher K, Norman G. Development and evaluation of the conceptual inventory of natural selection. J Res Sci Teach. 2002;39:952-78.

Antolin M. Evolutionary biology of disease and Darwinian medicine. In: Ruse M, Travis J, editors. Evolution: the first four billion years. Cambridge: Harvard University Press; 2009. p. 281-98.

Antolin M, Herbers J. Evolution's struggle for existence in America's public schools. Evolution. 2001;55:2379-88.

Armor DA, Taylor SE. When predictions fail: the dilemma of unrealistic optimism. In: Gilovich T, Griffin D, Kahneman T, editors. Heuristics and biases. The psychology of intuitive judgment. Cambridge: Cambridge University Press; 2002.

Asghar A, Wiles JR, Alters B. Canadian pre-service elementary teachers' conceptions of biological evolution and evolution education. McGill J Educ. 2007;28:673-95.

Audi R. Self-deception, rationalization, and reasons for acting. In: McLaughlin BP, Rorty AO, editors. Perspectives on selfdeception. Berkeley: University of California Press; 1988. p. 92-120.

Barefoot JC, Brummett BH, Williams RB, Siegler IC, Helms MJ, Boyle $\mathrm{SH}$, et al. Recovery expectations and long-term prognosis of patients with coronary heart disease. Arch Intern Med. 2011. doi:10.1001/archinternmed.2011.41.

Baum DA, Offner S. Phylogenetics and tree-thinking. Am Bio Teach. 2008;70:222-9.

Bering J. The belief instinct. The psychology of souls, destiny, and the meaning of life. New York: Norton; 2011.

Berkman MB, Plutzer E. Scientific expertise and the culture war: public opinion and the teaching of evolution in the American states. Perspect Polit. 2009;7:485-99.

Berkman MB, Plutzer E. Evolution, creationism, and the battle to control America's classrooms. New York: Cambridge University Press; 2010.

Berkman MB, Pacheco JS, Plutzer E. Evolution and creationism in America's classrooms: a national portrait. PLoS Bio. 2008. doi:10.1371/journal.pbio.0060124.

Birnbaum MH, Anderson C, Hyman LG. Theories of bias in probability judgment. In: Caverni JP, Fabre JM, Gonzalez M, editors. Cognitive biases. Amsterdam: North-Holland; 1990. p. 477-98.

Bishop G. Polls apart on human origins. Rep Natl Cent Sci Educ. 2007;27:35-41.

Bishop BA, Anderson CW. Student conceptions of natural selection and its role in evolution. J Res Sci Teach. 1990;27:89-91.

Blystone RV, Blodgett K. WWW: the scientific method. CBE Life Sci Educ. 2006;5:7-11.

Bowler PJ. The eclipse of Darwinism: anti-Darwinian evolutionary theories in the decades around 1900. Baltimore: Johns Hopkins University Press; 1983.

Bowman KL. The evolution battles in high-school science classes: who is teaching what? Front Ecol Environ. 2008;6:69-74.

Branch G. Creationism as a global phenomenon. In: Robbins R, Cohen M, editors. Darwin and the Bible: the cultural confrontation. Boston: Allyn \& Bacon; 2008. p. 137-51.

Brem SK, Ranney M, Schindel J. Perceived consequences of evolution: college students perceive negative personal and social impact in evolutionary theory. Sci Educ. 2003;87:181-206.

Bridgman PW. Reflections of a physicist. 2nd ed. Oxford: Clarendon; 1955.

Brown CM. Hindu responses to Darwinism: assimilation and rejection in a colonial and post-colonial context. Sci Educ. 2010;19:705-38.

Brown JH, Gibson AC. Biogeography. St. Louis: Mosby; 1983. 
Browne J. Darwin in caricature: a study in the popularization and dissemination of evolution. Proc Am Phil Soc. 2001;145:496-509.

Brumby MN. Misconceptions about the concept of natural selection by medical biology students. Sci Educ. 1984;68:493-503.

Brumfiel G. Intelligent design: who has designs on your students' minds? Nature. 2005;434:1062-5.

California Academy of Sciences. In: American adults flunk basic science. Science Daily. 2009. http://www.sciencedaily.com/ releases/2009/03/090312115133.htm. Accessed 1 Jun 2011.

Cantor G, Swetlitz M. Jewish tradition and the challenge of Darwinism. Chicago: University of Chicago Press; 2006.

Carver CS, Scheier MF, Segerstrom SC. Optimism. Clin Psychol Rev. 2010;30:879-89.

Catley KM, Novick LR. Digging deep: exploring college students' knowledge of macroevolutionary time. J Res Sci Teach. 2009;46:311-32.

Cavallo AML, McCall D. Seeing may not be believing: examining students' understandings and beliefs in evolution. Am Bio Teach. 2008;70:522-30.

Chalmers AF. What is this thing called science? 3rd ed. Indianapolis: Hackett; 1999.

Chi MTH. Common sense conceptions of emergent processes: why some misconceptions are robust. J Learn Sci. 2005;14:161-99.

Chinn CA, Malhotra BA. Children's responses to anomalous scientific data: how is conceptual change impeded? J Educ Psychol. 2002;94:327-43.

Chinn CA, Samarapungavan A. Distinguishing between understanding and belief. Theory Pract. 2001;40:235-41.

Cho MH, Lankford DM, Wescott DJ, Exploring the relationships among epistemological beliefs, nature of science, and conceptual change in the learning of evolutionary theory. Evol: Educ Outreach. 2011. doi:10.1007/s12052-011-0324-7.

Clark CA. "You are here": missing links, chains of being, and the language of cartoons. Isis. 2009;100:571-89.

Clough EE, Wood-Robinson C. How secondary students interpret instances of biological adaptation. J Bio Educ. 1985;19:125-30.

Cobern WW. Belief, understanding, and the teaching of evolution. J Res Sci Teach. 1994;31:583-90.

Cobern WW. The nature of science and the role of knowledge and belief. Sci Educ. 2000;9:219-46.

Colburn A, Henriques L. Clergy views on evolution, creationism, science and religion. J Res Sci Teach. 2006;43:419-42.

Cooper RA. The goal of evolution instruction: should we aim for belief or scientific literacy? Rep Natl Cent Sci Educ. 2001;21:148.

Cornish-Bowden A, Cárdenas ML. The threat from creationism to the rational teaching of biology. Biol Resch. 2007;40:113-22.

Cotner S, Brooks D, Moore R. Is the age of the earth one of our "sorest troubles?" Students' perceptions about deep time affect their acceptance of evolutionary theory. Evolution. 2010;64:85864.

Coyne JA. Why evolution is true. New York: Viking; 2009a.

Coyne JA. Seeing and believing. Review of "Saving Darwin: how to be a Christian and believe in evolution" by Gilberson K, and "Only a theory: evolution and the battle for America's soul" by Miller KR. The New Republic. 2009b;240:32-9.

Cummins CL, Demastes SS, Haffer MS. Evolution: biology education's under-researched unifying theme. J Res Sci Teach. 1994;31:445-8.

Cunningham DL, Wescott DJ. Still more "fancy" and "myth" than "facts" in students' conceptions of evolution. Evol: Educ Outreach. 2009;2:505-17.

Davson-Galle P. Understanding: 'knowledge', 'belief' and 'understanding'. Sci Educ. 2004;13:591-8.

Dawkins R. The blind watchmaker. Why the evidence of evolution reveals a universe without design. New York: Norton; 1996.
Dawkins R. Is science a religion? Humanist. 1997;57:26-9.

Dawkins R. The God delusion. Boston: Houghton Mifflin; 2006.

Deadman JA, Kelly PJ. What do secondary school boys understand about evolution and heredity before they are taught about the topics. J Bio Educ. 1978;12:7-15.

Demastes SS, Good RG, Peebles P. Students' conceptual ecologies and the process of conceptual change in evolution. Sci Educ. 1995a;79:637-66.

Demastes S, Settlage J, Good R. Students' conceptions of natural selection and its role in evolution: cases of replication and comparison. J Res Sci Teach. 1995b;32:535-50.

Deniz H, Donnelly LA. Preservice secondary science teachers' acceptance of evolutionary theory and factors related to acceptance. Repts Nat Ctr Sci Educ. 2011;31(4):7.

Dennett DC. Breaking the spell: religion as a natural phenomenon. New York: Viking; 2006.

Denton M. Evolution: a theory in crisis. New developments in science are challenging orthodox Darwinism. Bethesda: Adler \& Adler; 1986.

Diamond J, editor. Virus and the whale: exploring evolution in creatures small and large. Arlington: NSTA; 2006.

Discovery Institute, 2003, "The Wedge document": so what? www. discovery.org/scripts/viewDB/filesDB-download.php?id=349. Accessed 18 Feb 2007.

Dobzhansky T. Nothing in biology makes sense except in light of evolution. Am Biol Teach 1973;35:125-129

Downie JR, Barron NJ. Evolution and religion: attitudes of Scottish first year biology and medical students to the teaching of evolutionary biology. Biosci Educ E-Journal. 2000;4:1-18.

Duschl R, Grandy RE. Demarcation in science education. Toward an enhanced view of scientific method. In: Taylor RS, Ferrari M, editors. Epistemology and science education. Understanding the evolution vs. intelligent design controversy. New York: Routledge; 2011.

Edis T. An illusion of harmony: science and religion in Islam. Amherst: Prometheus Books; 2007.

Ellis J. How science works: evolution. Dordrecht: Springer; 2010.

Evans EM. The emergence of beliefs about the origins of species in school-age children. Merrill-Palmer Q. 2000a;46:19-52.

Evans EM. Beyond scopes: why creationism is here to stay. In: Rosengren K, Johnson C, Harris P, editors. Imagining the impossible: the development of magical, scientific, and religious thinking in contemporary society. Cambridge: Cambridge University Press; 2000b. p. 305-33.

Evans EM. Cognitive and contextual factors in the emergence of diverse belief systems: creation versus evolution. Cogn Psychol. 2001;42:217-66.

Evans EM. Conceptual change and evolutionary biology: a developmental analysis. In: Vosniadou S, editor. International handbook of research on conceptual change. New York: Routledge; 2008. p. $263-94$.

Evans EM, Spiegel A, Gram W, Frazier BF, Tare M, Thompson S, et al. A conceptual guide to natural history museum visitors' understanding of evolution. J Res Sci Teach. 2010;47:32653.

Falk JH, Dierking LD. The 95 percent solution. School is not where most Americans learn most of their science. Am Sci. 2010;98:48693.

Farber P. Teaching evolution and the nature of science. Am Bio Teach. $2003 ; 65: 347-54$.

Farley J. The initial reactions of French biologists to Darwin's "Origin of Species." J Hist Bio. 1974;7:275-300.

Ferrari M, Chi MTH. The nature of naïve explanations of natural selection. Intern J Sci Educ. 1998;20:1231-56.

Fine C. A mind of its own: how your brain distorts and deceives. New York: Norton; 2006. 
Fingarette H. Self-deception. London: Routledge Kegan \& Paul; 1969 (Reissued with a new chapter, Berkeley: University of California Press; 2000).

Forrest B, Gross PR. Creationism's Trojan horse. The wedge of intelligent design. Oxford: Oxford University Press; 2004.

Freeman S, Herron JC. Evolutionary analysis. 4th ed. Boston: Pearson Benjamin Cummings; 2007.

Futuyma DJ. Evolution. 2nd ed. Sunderland: Sinauer Associates; 2009.

Gauch HG. Scientific method in practice. Cambridge: Cambridge University Press; 2003.

Gibson MT. Culture wars in state education policy: a look at the relative treatment of evolutionary theory in state science standards. Soc Sci Q. 2004;85:1129-49.

Gish DT. Evolution: the fossils still say NO! El Cajon: Institute for Creation Research; 1995.

Golinski J. Making natural knowledge. Constructivism and the history of science. Cambridge: Cambridge University Press; 1998.

González Galli LM, Meinardi EN. The role of teleological thinking in learning the Darwinian model of evolution. Evol: Educ Outreach. 2011;4:145-52.

Gordon R, Franklin N, Beck J. Wishful thinking and source monitoring. Mem Cog. 2005;33:418-29.

Gould SJ. Darwin's delay. Nat Hist. 1974;83:68-70 (Reprinted (1977) In: Ever since Darwin. New York: Norton; pp. 21-27).

Grantham TA. Hierarchical approaches to macroevolution: recent work on species selection and the effect hypothesis. Ann Rev Ecol Syst. 1995;26:301-26.

Grantham TA. Hierarchies in evolution. In: Briggs DEG, Crowther PR, editors. Palaeobiology II. Oxford: Blackwell Science; 2001. p. $188-92$.

Greene ED. The logic of university students' misunderstanding of natural selection. J Res Sci Teach. 1990;27:875-85.

Gregory TR. Understanding evolutionary trees. Evol: Educ Outreach. 2008;1:121-37.

Gregory TR. Understanding natural selection: essential concepts and common misconceptions. Evol: Educ Outreach. 2009;2:15675.

Griffiths M. The cognitive psychology of gambling. J Gamb Stud. 1990;6:31-42.

Haack S. Defending science - within reason. Between scientism and cynicism. Paperback edition. Amherst, NY: Prometheus Books; 2007; p. 411 (Originally published 2003)

Hacking I. The emergence of probability. Cambridge: Cambridge University Press; 1975.

Harmon-Jones E, Mills J, editors. Cognitive dissonance. Progress on a pivotal theory in social psychology. Washington, DC: American Psychological Association; 1999.

Harrison P. Introduction. In: Harrision P, editor. The Cambridge companion to science and religion. Cambridge: Cambridge University Press; 2010. p. 1-17.

Harvey N. Wishful thinking impairs belief-desire reasoning: a case of decoupling failure in adults? Cognition. 1992;45:141-62.

Hazen RM, Trefil J. Science matters: achieving scientific literacy. New York: Anchor Books; 2009.

Hendry AP, Kinnison MT, Heino M, Day T, Smith TB, Fitt G, et al. Evolutionary principles and their practical application. Evol Appl. 2011;4:159-83.

Hofmann JR, Weber BH. The fact of evolution: implications for science education. Sci Educ. 2003;12:729-60.

Hofstadter R. Anti-intellectualism in American life. New York: Knopf; 1963.

Hokayem H, BouJaoude S. College students' perceptions of the theory of evolution. J Res Sci Teach. 2008;45:395-419.

Holland JH. Emergence: from chaos to order. Reading: Helix Books; 1998.
Hull DL. Darwin and his critics: the reception of Darwin's theory of evolution by the scientific community. Chicago: University of Chicago Press; 1973.

Hull DL. Defining Darwinism. Stud Hist Philos Bio Biomed Sci. 2011;42:2-4.

Ingram EL, Nelson CE. Relationship between achievement and students' acceptance of evolution or creation in an upper-level evolution course. J Res Sci Teach. 2006;43:7-24.

Isaacowitz DM. The gaze of the optimist. Personal Soc Psych Bull. 2005;31:407-15.

Isaak M. The counter-creationism handbook. Westport: Greenwood; 2006.

Jakobi SR. "Little monkeys on the grass..." How people for and against evolution fail to understand the theory of evolution. Evol: Educ Outreach. 2010;3:416-9.

Jansen LA, Appelbaum PS, Klein WMP, Weinstein N, Cook W, Fogel JS, et al. Unrealistic optimism in early-phase oncology trials. Ethics Hum Res. 2011;33:1-8.

Jensen MS, Finley FN. Teaching evolution using historical arguments in a conceptual change strategy. Sci Educ. 1995;79:147-66.

Jensen MS, Finley FN. Changes in students' understanding of evolution resulting from different curricular and instructional strategies. J Res Sci Teach. 1996;33:879-900.

Johnson PE. Darwin on trial. Washington, DC: Regnery Gateway; 1991.

Johnson PE. Reason in the balance. The case against naturalism in science, law and education. Downers Grove: InterVarsity; 1995.

Jungwirth E. The problem of teleology in biology as a problem of biology-teacher education. J Bio Educ. 1975;9:243-6.

Kahan DM, Jenkins-Smith H, Braman D. Cultural cognition of scientific consensus. Jour Risk Res. 2011;14:147-74.

Kampourakis K, McComas WF. Charles Darwin and evolution: illustrating human aspects of science. Sci Educ. 2010;19:63754.

Kampourakis K, Zogza V. Students' intuitive explanations of the causes of homologies and adaptations. Sci Educ. 2008;17:27-47.

Kelemen D. Why are rocks pointy? Children's preference for teleological explanations of the natural world. Dev Psychol. 1999a;35:1440-52.

Kelemen D. Beliefs about purpose: on the origins of teleological thought. In: Corballis MC, Lea SEG, editors. The descent of mind: psychological perspectives on hominid evolution. New York: Oxford University Press; 1999b. p. 278-94.

Kelemen D. Functions, goals and intentions: children's teleological reasoning about objects. Trends Cogn Sci. 1999c;12:461-8.

Kelemen D. Teleological minds: how natural intuitions about agency and purpose influence learning about evolution. In: Rosengren K, Sinatra G, Brem S, Evans M, editors. Evolution challenges: integrating research and practice in teaching and learning about evolution. Oxford: Oxford University Press; 2011; in press

Kida T. Don't believe everything you think. The six basic mistakes we make in thinking. Amherst: Prometheus Books; 2006.

Krizan Z, Windschitl PD. Wishful thinking about the future: does desire impact optimism? Soc Pers Psychol Compass. 2009;3:22743.

Kugler C. Darwin's theory, Mendel's laws: labels and the teaching of science. Am Bio Teach. 2002;64:341-51.

Lachman SP. One nation under God: religion in contemporary American society. New York: Harmony Books; 1993.

Largent MA. Darwin's analogy between artificial and natural selection in the Origin of Species. In: Ruse M, Richards RJ, editors. The Cambridge companion to the "Origin of Species." Cambridge: Cambridge University Press; 2009. p. 14-29.

Lawson AE. Predicting science achievement: the role of developmental level, disembedding ability, mental capacity, prior knowledge and beliefs. J Res Sci Teach. 1983;19:233-48. 
Lawson AE. A review of research on formal reasoning and science teaching. J Res Sci Teach. 1985;22:569-618.

Lawson AE, Thompson LD. Formal reasoning ability and misconceptions concerning genetics and natural selection. J Res Sci Teach. 1988;25:733-46.

Lawson AE, Weser J. The rejection of nonscientific beliefs about life: effects of instruction and reasoning skills. J Res Sci Teach. 1990;27:589-606.

Lawson AE, Worsnop WA. Learning about evolution and rejecting a belief in special creation: effects of relative reasoning skill, prior knowledge, prior belief and religious commitment. J Res Sci Teach. 1992;29:143-66.

Lazar A. Deceiving oneself or self-deceived? On the formation of beliefs "under the influence." Mind. 1999;108:265-90.

Lederman NG. Students' and teachers' conceptions about the nature of science: a review of the research. J Res Sci Teach. 1992;29:331-59.

Lederman NG. Nature of science: past, present, and future. In: Abell SK, Lederman NG, editors. Handbook of research on science education. Mahwah: Erlbaum; 2004. p. 831-80.

Lennox JG. Darwin was a teleologist. Biol Philos. 1993;8:409-21.

Liang C, Dunn P. In: Are entrepreneurs optimistic, realistic, both or fuzzy? Relationship between entrepreneurial traits and entrepreneurial learning. Acad Entrep J. 2008. http://findarticles.com/p/ articles/mi_hb6005/is_1-2_14/ai_n32106818/?tag=content;coll. Accessed 19 Jul 2011

Lipps J. The decline of reason? In: Scotchmoor J, McKinney FK, editors. Learning from the fossil record. The Paleontological Society papers, vol. 2. Lawrence: The Paleontological Society; 2006. p. 3-10.

Livingstone D. Darwin's forgotten defenders: the encounter between evangelical theology and evolutionary thought. Grand Rapids: Eerdmans; 1984.

Lombrozo T, Shtulman A, Weisberg M. The intelligent design controversy: lessons from psychology and education. Trends Cogn Sci. 2006;10:56-7.

Lombrozo T, Thanukos A, Weisberg M. The importance of understanding the nature of science for accepting evolution. Evol: Educ Outreach. 2008;1:290-8.

Lord T, Marino S. How university students view the theory of evolution. Jour Col Sci Teach. 1993;22:353-7.

Lovallo D, Kahneman D. Delusions of success: how optimism undermines executives' decisions. Harv Bus Rev. 2003;81:5663.

Lovely EC, Kondrick LC. Teaching evolution: challenging religious preconceptions. Integr Comp Bio. 2008;48:164-74.

Martin JW. Compatibility of major U.S. Christian denominations with evolution. Evol: Educ Outreach. 2010;3:420-31.

Mayr E. The growth of biological thought: diversity, evolution, and inheritance. Cambridge: Harvard University Press; 1982.

Mayr E. What is Darwinism today? Proc Bienn Meet, Philos Sci Assoc. 1986;2:145-56.

Mayr E. Cause and effect in biology. In: Mayr E, editor. Toward a new philosophy of biology. Cambridge: Harvard University Press; 1988. p. 67-74.

Mazur A. Believers and disbelievers in evolution. Pol Life Sci. 2005;23:55-61.

McComas WF. Science and its myths. The skeptic encyclopedia of pseudoscience. Santa Barbara: ABC CLIO; 2002. p. 430-42.

McComas WF, Almazroa H, Clough MPO. The nature of science in science education: an introduction. Sci Educ. 1998;7:511-32.

McDonald CV. The influence of explicit nature of science and argumentation instruction on preservice primary teachers' views of nature of science. J Res Sci Teach. 2010;47:1137-64.

McKeachie WJ, Lin YG, Strayer J. Creationist vs. evolutionary beliefs: effects on learning biology. Am Bio Teach. 2002;64:189-92.
McVaugh NK, Birchfield J, Lucero MM, Petrosino AJ. Evolution education: seeing the forest for the trees and focusing our efforts on the teaching of evolution. Evol: Educ Outreach. 2011;4:28692.

Mead LS, Scott EC. Problem concepts in evolution part I: purpose and design. Evol: Educ Outreach. 2010a;3:78-81.

Mead LS, Scott EC. Problem concepts in evolution part II: cause and chance. Evol: Educ Outreach. 2010b;3:261-4.

Meadows L. The missing link. An inquiry approach for teaching all students about evolution. Portsmouth: Heinemann; 2009.

Meisel RP. Teaching tree-thinking to undergraduate biology students. Evol: Educ Outreach. 2010. doi:10.1007/s12052-010-0254-9.

Miller KR. Finding Darwin's God: a scientist's search for common ground between God and evolution. New York: Harper Perennial; 1999.

Miller JD. The conceptualization and measurement of civic scientific literacy for the twenty-first century. In: Meinwald J, Hildebrand JG, editors. Science and the educated American: a core component of liberal education. Cambridge: American Academy of Arts and Sciences; 2010. p. 241-54.

Miller JD, Scott EC, Okamoto S. Public acceptance of evolution. Science. 2006;313:765-6.

Mindel D. The evolving world. Evolution in everyday life. Cambridge: Harvard University Press; 2006.

Mooney C. We can't handle the truth. The science of why we don't believe science. Mother Jones. 2011;36:40-5.

Mooney C, Kirschenbaum S. Unscientific America. How scientific illiteracy threatens our future. New York: Basic Books; 2009.

Moore JA. Science as a way of knowing. Cambridge: Harvard University Press; 1993.

Moore R. Creationism in the biology classroom: what do teachers teach and how do they teach it? Am Bio Teach. 2008;70:79-84.

Moore R, Cotner S. Rejecting Darwin: the occurrence and impact of creationism in high school biology classrooms. Am Bio Teach. 2009;70:79-84.

Moore R, Mitchell G, Bally R, Inglis M, Day J, Jacobs D. Undergraduates' understanding of evolution: ascriptions of agency as a problem for student learning. J Bio Educ. 2002;36:65-70.

Moreland JP. Christianity and the nature of science. Grand Rapids: Baker Book House; 1989.

Nadelson LS, Southerland SA. Examining the interaction of acceptance and understanding: how does the relationship change with a focus on macroevolution? Evol: Educ Outreach. 2010;3:82-8.

Nanda M. Prophets facing backward: postmodern critiques of science and Hindu nationalism in India. New Brunswick: Rutgers University Press; 2003.

National Academy of Sciences. Teaching about evolution and the nature of science. Washington, DC: National Academy; 1998.

National Research Council. Learning science in informal environments: people, places, and pursuits. In: Committee on Learning Science in Informal Environments, Bell P, Lewenstein B, Shouse A W, Feder M A, editors. Washington, DC: National Academies; 2009.

Nehm RH, Reilly L. Biology majors' knowledge and misconceptions of natural selection. BioSci. 2007;57:263-72.

Nehm RH, Schonfeld IS. Does increasing biology teacher knowledge of evolution and the nature of science lead to greater preference for the teaching of evolution in schools? J Sci Teach Educ. 2007;18:699-723.

Nehm RH, Kim SY, Sheppard K. Academic preparation in biology and advocacy for teaching evolution: biology versus non-biology teachers. Sci Educ. 2009;93:1122-46.

Nehm RH, Rector MA, Ha M. "Force-talk" in evolutionary explanation: metaphors and misconceptions. Evo Edu Outreach 2010;3:605-613.

Nelson CE. Teaching evolution effectively: a central dilemma and alternative strategies. McGill J Educ. 2007;42:265-83. 
Nelson CE. Teaching evolution (and all of biology) more effectively: strategies for engagement, critical reasoning, and confronting misconceptions. Integr Comp Bio. 2008;48:213-25.

Nelson CE, Nickels MK, Beard J. The nature of science as the foundation for teaching science: evolution as a case study. In: McComas WF, editor. The nature of science in science education. Dordrecht: Kluwer Academic; 1998.

Newell ND. Why scientists believe in evolution. Alexandria: American Geological Institute; 1984.

Nickels MN, Nelson CE, Beard J. Better biology teaching by emphasizing evolution and the nature of science. Am Bio Teach. 1996;58:332-6.

Numbers RL. The creationists. Expanded ed. Cambridge: Harvard University Press; 2006.

O'Brien DT, Wilson DS, Hawley PH. "Evolution for Everyone": a course that expands evolutionary theory beyond the biological sciences. Evol: Educ Outreach. 2009;2:445-57.

Oliveira AW, Cook K, Buck GA. Framing evolution discussion intellectually. J Res Sci Teach. 2011;48:257-80.

Osif BA. Evolution and religious beliefs: a survey of Pennsylvania high school teachers. Am Bio Teach. 1997;59:552-6.

Padian K. How to win the evolution war: teach macroevolution. Evol: Educ Outreach. 2010;3:206-14.

Padian K, Angielczyk KD. Are there transitional forms in the fossil record? In: Kelley PH, Bryan JR, Hansen TA, editors. The evolution-creation controversy II: perspectives on science, religion, and geological education. The Paleontological Society papers, vol. 5. Lawrence: The Paleontological Society; 1999. p. 47-82.

Parsons KM, editor. The science wars: debating scientific knowledge and technology. Amherst: Prometheus Books; 2003.

Paterson FRA, Rossow LF. "Chained to the devil's throne": evolution and creation science as a religio-political issue. Am Bio Teach. 1999;61:358-64.

Paz-y-Miño C, Espinosa G. New England faculty and college students differ in their views about evolution, creationism, intelligent design, and religiosity. Evol: Educ Outreach. 2010. doi:10.1007/ s12052-010-0298-x

Pedersen S, Halldén O. Intuitive ideas and scientific explanations as parts of students' developing understanding of biology: the case of evolution. Eur J Psychol Educ. 1994;9:127-37.

Pennock RT. Naturalism, evidence and creationism: the case of Phillip Johnson. Biol Philos. 1996;11:543-59.

Pennock RT. Tower of Babel: the evidence against the new creationism. Cambridge: MIT; 1999.

People for the American Way Foundation. Evolution and creationism in public education: an in-depth reading of public opinion. Danbury: DYG, Inc.; 2000.

Pierce C. Idiot America: how stupidity became a virtue in the land of the free. New York: Doubleday; 2009.

Pigliucci M. Denying evolution. Creationism, scientism, and the nature of science. Sunderland: Sinauer Associates; 2002

Pigliucci M. The evolution-creation wars: why teaching more evolution just is not enough. McGill J Educ. 2007;42:285-306.

Plutzer E, Berkman E. Evolution, creationism, and the teaching of human origins in schools. Public Opin Q. 2008;72:540-53.

Pohl RF. Cognitive illusions. A handbook on fallacies and biases in thinking, judgment and memory. New York: Psychology; 2004.

Poling DA, Evans EM. Religious belief, scientific expertise, and folk ecology. J Cogn Cult. 2004;4:485-524.

Popper KR. The logic of scientific discovery. New York: Basic Books; 1959.

Pramling N. The role of metaphor in Darwin and the implications for teaching evolution. Sci Educ. 2008;93:535-47.

Prothero D. Evolution. What the fossils say and why it matters. New York: Columbia University Press; 2007
Provine WB. Evolution, religion, and science. In: Clayton P, Simpson $Z$, editors. The Oxford handbook of religion and science. Oxford: Oxford University Press; 2006. p. 667-80.

Provine WB. Afterword. In: The origins of theoretical population genetics. (Originally published 1971.) Chicago: University of Chicago Press; 2001. p. 197-205.

Reid GB. Biological emergences. Evolution by natural experiment. Cambridge: MIT; 2007.

Reiss JO. Not by design. Retiring Darwin's watchmaker. Berkeley: University of California Press; 2009.

Richards RA. Philosophical challenges in teaching evolution. Evol: Educ Outreach. 2008;1:158-64.

Robbins RH, Cohen MN. Darwin and the Bible. The cultural confrontation. Boston: Allyn \& Bacon; 2008.

Rosset E. It's no accident: our bias for intentional explanations. Cognition. 2008;108:771-80.

Rudolph JL. Reconsidering the 'nature of science' as a curriculum component. J Curric Stud. 2000;32:403-19.

Rudolph JL, Stewart J. Evolution and the nature of science: on the historical discord and its implications for education. J Res Sci Teach. 1998;35:1069-89.

Ruse M. Darwinism. In: Keller EF, Lloyd EA, editors. Keywords in evolutionary biology. Cambridge: Harvard University Press; 1992. p. 74-80.

Ruse M. The Darwinian revolution. Science red in tooth and claw. 2nd ed. Chicago: University of Chicago Press; 1999.

Ruse M. Can a Darwinian be a Christian? Cambridge: Cambridge University Press; 2001.

Ruse M. Darwinism and mechanism: metaphor in science. Stud Hist Phil Biol Biomed Sci. 2005;36:285-302.

Rutledge ML, Mitchell MA. High school biology teachers' knowledge structure, acceptance and teaching of evolution. Am Bio Teach. 2002;64:21-8.

Rutledge ML, Sadler KC. Reliability of the measure of acceptance of the theory of evolution (MATE) instrument with university students. Am Bio Teach. 2007;69:332-5.

Rutledge ML, Warden MA. The development and validation of the measure of acceptance of the theory of evolution instrument. Sch Sci Math. 1999;99:13-8.

Rutledge L, Warden MA. Evolutionary theory, the nature of science and high school biology teachers: critical relationships. Am Bio Teach. 2000;62:23-31.

Sagan C. The demon-haunted world: science as a candle in the dark. New York: Ballantine Books; 1996.

Samarapungavan A, Wiers RW. Children's thoughts on the origin of species: a study of explanatory coherence. Cogn Sci. 1997;21:14777.

Sandvik H. Tree thinking cannot be taken for granted: challenges for teaching phylogenetics. Theor Biosci. 2008;127:45-51.

Scharmann LC, Smith MU, James MC, Jensen M. Explicit reflective nature of science instruction: evolution, intelligent design, and umbrellaology. J Res Sci Teach. 2005;16:27-41.

Scott EC. Evolution vs. creationism. 2nd ed. Berkeley: University of California Press; 2009.

Scott EC, Branch G. Don’t call it "Darwinism." Evol: Educ Outreach. 2009;2:90-4.

Scott-Kakures D. Self-deception and internal irrationality. Philos Phenom Res. 1996;56:31-56.

Shanks N. God, the Devil, and Darwin. A critique of intelligent design theory. Oxford: Oxford University Press; 2004.

Sharot T. The optimism bias. A tour of the irrationally positive brain. New York: Pantheon; 2011.

Shermer M. Why Darwin matters. The case against intelligent design. New York: Times Books; 2006.

Shermer M. Why people believe weird things: pseudoscience, superstition, and other confusions of our time. New York: MJF Books; 2007. 
Shermer M. The believing brain. From ghosts and gods to politics and conspiracies - How we construct beliefs and reinforce them as truths. New York: Times Books; 2011

Shtulman A. Qualitative differences between naïve and scientific theories of evolution. Cogn Psychol. 2006;52:170-94.

Shtulman A. Why people do not understand evolution. An analysis of the cognitive barriers to fully grasping the unity of life. Skeptic. 2011;16:2-6.

Shtulman A, Schulz L. The relation between essentialist beliefs and evolutionary reasoning. Cogn Sci. 2008;32:1049-62.

Shtulman A, Calabi P. Learning, understanding, and acceptance: the case of evolution. In: Love BC, McRae K, Sloutsky VM, editors. Proc $30^{\text {th }}$ Ann Conf Cogn Sci Soc, Austin; 2008. p. 235-40

Sinatra GM, Southerland SA, McConaughy F, Demastes JW. Intentions and beliefs in students' understanding and acceptance of biological evolution. J Res Sci Teach. 2003;40:510-28.

Sinatra GM, Brem SK, Evans EM. Changing minds? Implications of conceptual change for teaching and learning about biological evolution. Evol: Educ Outreach. 2008;1:189-95.

Sinclair A, Pendarvis MP. The relationship between college zoology students' beliefs about evolutionary theory and religion. J Res Dev Educ. 1997;30:118-25.

Slotta JD, Chi MT. Helping students understand challenging topics in science through ontology training. Cogn Instr. 2006;24:261-89.

Smith MU. Current status of research in teaching and learning evolution: I. Philosophical/epistemological issues. Sci Educ. 2010a;19:523-38.

Smith MU. Current status of research in teaching and learning evolution: II. Pedagogical issues. Sci Educ. 2010b;19:539-71.

Smith MU, Siegel H. Knowing, believing, and understanding: what goals for science education? Sci Educ. 2004;13:553-82.

Smith MU, Siegel H, McInerney JD. Foundational issues in evolution education. Sci Edu. 1995;4:23-46.

Sokal AD. Beyond the hoax. Science, philosophy and culture. New York: Oxford University Press; 2008.

Southerland SA, Nadelson LS. The development and evaluation of the measure of understanding of macroevolution: introducing the MUM. J Exp Educ. 2011;78:151-90.

Southerland SA, Sinatra GM, Matthews M. Belief, knowledge, and science education. Educ Psychol Rev. 2001;13:325-51.

Sutherland S. Irrationality: the enemy within. New York: Penguin; 1994.

Tamir P, Zohar A. Anthropomorphism and teleology in reasoning about biological phenomena. Sci Educ. 1991;75:57-67.

Thagard P, Findlay S. Getting to Darwin: obstacles to accepting evolution by natural selection. Sci Educ. 2009. doi:10.1007/ s11191-009-9204-8.
Thompson JN. Use the word evolution. Evol: Educ Outreach. 2008;1:42-3.

Thomson KS. The meanings of evolution. Am Sci. 1982;70:529-31.

Tracy JL, Hart J, Martens JP. Death and science: the existential underpinnings of belief in intelligent design and discomfort with evolution. PLoS ONE. 2011. doi:10.1371/journal.pone.0017349

Trani RI. Won't teach evolution: it's against my religion. And now for the rest of the story. Am Bio Teach. 2004;66:419-27.

Trivers R. Social evolution. Menlo Park: Benjamin Cummings; 1985.

Verhey SD. The effect of engaging prior learning on students' attitudes towards creationism and evolution. BioSci. 2005;55:996-1003.

Watts DJ. Everything is obvious: *Once you know the answer. New York: Crown Business; 2011.

Weinberg S. Peace at last? In: Labinger JA, Collins H, editors. The one culture? A conversation about science. Chicago: University of Chicago Press; 2001. p. 238-40.

Weiss K. Biology's theoretical kudzu: the irrepressible illusion of teleology. Evol Anthr. 2002;11:4-8.

Wells J. Icons of evolution: science or myth? Why much of what we teach about evolution is wrong. Washington, DC: Regnery; 2002.

Wells W, Moriarty S, Burnett J. Advertising. Principles and practice. 7th ed. Upper Saddle River: Pearson Prentice Hall; 2006.

Wiles JR. Overwhelming scientific confidence in evolution and its centrality in science education - and the public disconnect. Sci Educ Rev. 2010;9:18-27.

Wiles JR, Alters B. Effects of an educational experience incorporating an inventory of factors potentially influencing student acceptance of biological evolution. Int J Sci Educ. 2011. doi:10.1080/ 09500693.2011.565522

Williams JD. Belief versus acceptance: why do people not believe in evolution? BioEssays. 2009;3:1255-62.

Wilson DS. Evolution for everyone: how to increase acceptance of, interest in, and knowledge about evolution. PLoS Bio. 2005;3: e364. doi:10.1371/journal.pbio.0030364.

Wilson DS. Evolution for everyone: how Darwin's theory can change the way we think about our lives. New York: Delacorte; 2007.

Wolpert L. Six impossible things before breakfast: the evolutionary origins of belief. London: Faber and Faber; 2006.

Woods CS, Scharmann LC. High school students' perceptions of evolutionary theory. Electronic J Sci Educ. 2001;6(2).

Yacoubian HA, BouJaoude S. The effect of reflective discussions following inquiry-based laboratory activities on students' views of nature of science. J Res Sci Teach. 2010;47:1229-52.

Young RM. Darwin's metaphor. Nature's place in Victorian culture. Cambridge: Cambridge University Press; 1985.

Ziman J. Real science. What it is, and what it means. Cambridge: Cambridge University Press; 2000. 